\title{
Characterization of the nuclear ribosomal DNA unit in Oxalis tuberosa (Oxalidacea) and related species
}

\author{
Daniela Tosto* \\ Unidad Integrada de Investigación y Docencia \\ Instituto de Biotecnología Centro Nacional de Investigaciones Agropecuarias \\ Instituto Nacional de Tecnología Agropecuaria \\ Departamento de Ecología Genética y Evolución \\ Facultad de Ciencias Exactas y Naturales \\ Universidad de Buenos Aires \\ Las Cabañas y Los Reseros, B1712WAA Castelar, Argentina \\ Tel: 54114621 1447. Ext 152 \\ Fax: 541146210199 \\ E-mail: dtosto@cnia.inta.gov.ar \\ Esteban Hopp \\ Unidad Integrada de Investigación y Docencia \\ Instituto de Biotecnología Centro Nacional de Investigaciones Agropecuarias \\ Instituto Nacional de Tecnología Agropecuaria \\ Departamento de Fisiología, Biología Molecular y Celular \\ Facultad de Ciencias Exactas y Naturales \\ Universidad de Buenos Aires \\ Las Cabañas y Los Reseros, B1712WAA Castelar, Argentina \\ Tel: 54114621 1447. Ext 152 \\ Fax: 541146210199 \\ E-mail: ehopp@cnia.inta.gov.ar
}

\begin{abstract}
Financial support: Proyecto Específico (AEBIO2443) Instituto Nacional de Tecnología Agropecuaria, "Filogeografía e implementación de un sistema de monitoreo molecular de la identidad genética de cultivos andinos".
\end{abstract}

Keywords: Andean crops, oca, Oxalis, rDNA, RFLPs.

Abbreviations: IGS: intergenic spacer

ITS: internal transcribed spacers

PAES: polyanethole sulfonic acid

SDS: sodium dodecylsulfate

Oxalis tuberosa is an octoploid Andean tuber crop called "oca" that belongs to the worldwide distributed genus Oxalis. The genus is very heterogeneous and its systematics is still problematic. It has been proposed that $O$. tuberosa evolved by polyploidization of a still not defined ancestor that belongs to an alliance of species sharing the same basic chromosome number $(x=8)$. Nuclear rDNA units of $O$. tuberosa and a selected group of four related diploid species were characterised by RFLP using different restriction endonucleases and southern hybridization probes to produce a restriction map for EcoRI and BamHI. The major rDNA unit length in $O$. tuberosa was estimated at $10.7 \mathrm{kbp}$. As expected, restriction site variation was observed mainly in the intergenic spacer (IGS), but was also detected in coding regions. Restriction site mapping organization of the transcribed rDNA unit of $O$. tuberosa is very similar to $O$. oblongiformis. Nucleotide sequencing of a region of o. peduncularis IGS generated a complex organization pattern of repeats and subrepeats. Diploid species $\boldsymbol{O}$. peduncularis, $O$. tabaconasensis and $O$. aff. villosula exhibited a ladder pattern that is a consequence of a 170 bp subrepeat unit indicating that these species share organization similarity and sequence homology. The variation pattern provided information to compare among diploid species, although it did not help to clarify taxonomic relationships between $O$. tuberosa and the putative diploid ancestors analysed in this study. Nonetheless, the RFLP pattern exhibited by $O$. tuberosa for the IGS region was quite unique and will be a useful tool to prospect in other related species.

The genus Oxalis is distributed worldwide and is represented by at least 800 species, most of them in the southern hemisphere and mainly in America and South Africa (Lourteig, 1983). Cytogenetic studies revealed a great deal of variability in the basic number of chromosomes (from $\mathrm{x}=5$ to $\mathrm{x}=12$ ), as well as variation in the ploidy degree, ranging from 2x to 8x (Marks, 1956; Cronquist, 1981; Naranjo et al. 1982; de Azkue and

*Corresponding author 
Martínez, 1983; de Azkue and Martínez, 1984; de Azkue and Martínez, 1988; de Azkue and Martínez, 1990). Within the genus, a group of species shares the same basic number of chromosomes ( $x=8)$ (de Azkue and Martínez, 1990). This group has particular economic importance because it includes the octoploid Oxalis tuberosa Mol., an Andean crop commonly known as "oca", that is unique in this alliance due to its domestication by pre-Columbian civilizations. This crop is still widely cultivated in the Andean regions from Venezuela to Argentina (Hodge, 1951; Cárdenas, 1969; King, 1987). Out of this region, O. tuberosa is commercially cultivated in Mexico and New Zealand (New Zealand yam) (León, 1964; Vietmeyer, 1986).

Due to the importance of this crop in 1990 de Azkue and Martínez (de Azkue and Martínez, 1990) proposed the name "Oxalis tuberosa alliance" to this group of $\mathrm{x}=8$ species. However, these species are separated in different sections according to Knuth's taxonomical classification of the genus (Knuth, 1930; Knuth, 1935; Knuth, 1936). This grouping is also not concordant with the recent revision of Alicia Lourteig (Lourteig, 2000) who has introduced some new names, has reduced others to synonymy and has reassigned species to different sections.

The basic organization of ribosomal DNA has been maintained in most eukaryotic systems. It is organized in large arrays or blocks of tandemly repeated units, which occur at one or more chromosome locations; each of them considered as an individual genetic locus. In plants, their copy number can vary from few hundred to several thousand. One repeating unit consists of the conserved 18S,
5.8S and 25S rDNA coding regions and the corresponding internal transcribed spacers (ITS) as well as intergenic spacers (IGS) (Rogers and Bendich, 1987). The rDNA units can vary in length, in base sequence (restriction site variation) and in the number of repeats per species, these types of variation has been described for many plant species (Appels and Dvorak, 1982; May and Appels, 1987; Zimmer et al. 1988; Baldwin et al. 1995; Volkov et al. 1996; Pillay, 1996; Polanco and Pérez de la Vega, 1997; Warpeha et al. 1998; Chou et al. 1999; Volkov et al. 1999a; Fernández et al. 2000; Bhagwat et al. 2001; Gupta et al. 2002; Hsieh et al. 2004; Hsieh et al. 2005; Pillay and Kenny, 2006). ITS regions are more variable than the rRNA genes but are more conserved than the IGS regions. The coding region is highly conserved, whereas the IGS region is variable in sequence and length and show interand intra- specific variation (Rogers and Benedich, 1987).

Intraspecific IGS length variability is generally associated with different numbers motifs referred to as subrepeats that range from 40 to $400 \mathrm{bp}$ in length in plants (e.g. $40 \mathrm{bp}$ in Sisymbrium irio, Grellet et al. 1989; 115 bp in barley Saghai-Maroof et al. 1984; Gupta et al. 2002; 130 bp in wheat, Appels and Dvorak, 1982; May and Appels, 1987; 340 bp in alfalfa Cluster et al. 1996; 460 bp in carrot Taira et al. 1988). The length and sequence of subrepeats within most individual species are quite conserved. However, the number of subrepeats within a rDNA repeat is often quite variable at different NOR loci within species and also at the same NOR locus in different individuals at the same species. The variation in the number of subrepeats alters the length of the entire IGS region leading to the occurrence of spacer length variants that can be detected by restriction

Table 1. Chromosome number and collection locality of the Oxalis species.

\begin{tabular}{|c|c|c|c|}
\hline Species & Locality & $2 \mathbf{n}$ & Herb No/ Acc. No \\
\hline O. oblongiformis Knuthc & Perú, Amazonas, Chachapoyas, near Balsas & 16 & $2917^{\mathrm{a}}$ \\
\hline O. peduncularis H.B.K. & Perú, Cajamarca, Cenedin, Quilimbash & 16 & $2908^{\mathrm{a}}$ \\
\hline O. tabaconanensis Knuth ${ }^{\mathrm{C}}$ & Perú, Amazonas, Bongara, near Pomacocha & 16 & $2872^{\mathrm{a}}$ \\
\hline O. aff. villosula Knuth & Perú, Amazonas, Bongara, Churruja & 16 & $2901^{a}$ \\
\hline O. tuberosa MOL & Argentina, Salta, Santa Victoria & 64 & $1074^{\mathrm{b}}$ \\
\hline O. tuberosa MOL & Argentina, Jujuy, Tumbaya & 64 & $1018^{b}$ \\
\hline O. tuberosa MOL & Argentina, Jujuy, Yavi & 64 & $1051^{\mathrm{b}}$ \\
\hline
\end{tabular}

${ }^{\text {a }}$ BACP (Cefaprin, Buenos Aires).

${ }^{b}$ CIP Germplasm and INTA- Cerrillos Germplasm.

${ }^{\mathrm{c}}$ In the last monography involving the taxonomic treatment of genus Oxalis published by Lourteig (2000), she considered $O$. oblongiformis synonymous to $O$. tabaconasensis. Despite her observation, we decided to use both names in this work, since the analysis of rDNA sequence organization of the "two species" showed that they differed considerably. 
enzyme digestion coupled whit Southern hybridization (Appels et al. 1980; Appels and Dvorack, 1982; Grellet et al. 1989; Sano and Sano, 1990; Clegg, 1990; Maggini et al. 1992; Lakshmikumaran et al. 1994; Cluster et al. 1996; Jeandroz et al. 1996; Gupta et al. 2002 and reference there are in; Skalická et al. 2003; Lim et al. 2004; Kovarik et al. 2005).

Despite the demonstrated analytical power of this comparative information for systematic clarification, the study of rDNA organization (and its variation) in Oxalis is still lacking. In this context, previous studies of rDNA using the ITS support the O. tuberosa alliance hypothesis (Tosto and Hopp, 1996; Emshwiller and Doyle, 1998). The naturalness of the group has been also supported by other studies based on the chloroplast- expressed glutamine synthetase (Emshwiller and Doyle, 1999; Emshwiller and Doyle, 2002) and AFLPs (Tosto and Hopp, 2000).

In the present work, we analyse the restriction fragment length polymorphism of rDNA units as a first step to characterise the rDNA variation in O. tuberosa and in five related species that will help to provide a clue to clarify the species relationships.

\section{MATERIALS AND METHODS}

\section{Plant material}

The species of the genus Oxalis used in this study were: $O$. peduncularis, $O$. oblongiformis, $O$. tabaconasensis, $O$. aff. villosula and $O$. tuberosa. The different species were chosen as representatives of three of the four different sections (according to Knuth, 1930; Knuth,1935; Knuth, 1936, classification) that are present in the alliance. The only exception, section Herrerea, is not represented because $O$. herrerae, the only species that belongs to this section, was not available for this work. From section Ortgieseae we have chosen two species (apart from $O$. tuberosa) because it is the section where $O$. tuberosa belongs to.

The collection locality of the plants, their herbarium accession and chromosome number are detailed in Table 1. Voucher specimens of the diploid species examined are kept in the herbarium of CEFAPRIN (BACP). Clones of analyzed plants of $O$. tuberosa are kept at the germplasm bank of the International Potato Center (CIP) at Quito, Ecuador and at the germplasm bank of the INTA- Cerrillos, Salta, Argentina.

\section{DNA isolation, digestion and hybridization}

Leaf material was harvested and stored at $-70^{\circ} \mathrm{C}$ until DNA extraction. Total DNA was isolated from 4 gr of frozen leaf material from individual plants following the Dellaporta procedure (Dellaporta, 1983) with slight modifications. Routinely 3-5 $\mu$ g samples of each DNA were digested for 4 hrs at $37^{\circ} \mathrm{C}$ with $10 \mathrm{IU}$ of restriction endonucleases according to the supplier's recommendations and using the supplied buffers. DNA restriction fragments were separated by electrophoresis in $1 \%$ agarose gels in $0.04 \mathrm{M}$ Trisacetate $2 \mathrm{mM}$ EDTA (pH 7) buffer at $40 \mathrm{~V} / \mathrm{cm}$ for $15 \mathrm{hrs}$. As size marker, the $1 \mathrm{~kb}$ ladder of Life Technologies (USA) was included in the electrophoresis as well as the HindIIIdigested fragments from lambda phage DNA. Ethidium bromide was used to stain gels for documentation purposes. Southern blotting was performed using Hybond N nylon membranes (Amersham Pharmacia, UK) according supplier's recommendations. DNA probes (approximately $25 \mathrm{ng}$ ) were labeled using the Random Primed DNA labelling kit of Boehringer Mannheim in the presence of 20 $\mu \mathrm{Ci} \alpha^{32} \mathrm{P}$-dCTP $(3000 \mathrm{Ci} / \mathrm{nmol})$. Nylon menbranes were prehybridized and hybridized at $65^{\circ} \mathrm{C}$ for $16 \mathrm{hrs}$ in the presence of polyanethole sulfonic acid (PAES) 0.1\%, sodium pyrophosphate $0.1 \%$, SSPE $2.5 \%$ and sodium dodecylsulfate (SDS) $1 \%$. Final wash was for $15 \mathrm{~min}$ at $65^{\circ} \mathrm{C}$ in $0.2 \times \mathrm{SSC}$ ( $\mathrm{SSC}$ is $0.15 \mathrm{M} \mathrm{NaCl}, 0.015 \mathrm{M}$ Sodium citrate $\mathrm{pH} 7$ ), $0.1 \%$ SDS buffer. DNA fragment sizes were estimated after transforming their relative mobility into kbp using the local reciprocal method (Elder and Southern, 1983). After each hybridization, filters were reused with the successive probes to ensure optimal comparison between bands revealed in each case. To do so, they were stripped after hybridization by washing with boiling low-salt buffer (0.01x SSC) before re-probing.

\section{DNA probes}

a.- The $8.95 \mathrm{kbp}$ Eco RI fragment of wheat rDNA cloned in pTA71 (Gerlach and Bedbrook, 1979) as heterologous probe.

b.- The internal transcribed spacers ITS1, ITS2 and the $5.8 \mathrm{~S}$ rDNA (ITS) were obtained from $O$. oblongiformis and $O$. tuberosa DNA by PCR using the following primers: 5' TCC TCC GCT TAT TGA TATGC 3' (ITS4) and 5' GGA AGG AGA AGT CGT AAC AAG G 3'(ITS5).

c.- An EcoRI- BamHI fragment (1000 bp) corresponding to the 3 ' end of the $25 \mathrm{~S}$ fragment of wheat rDNA (May and Appels, 1987).

d.- The IGS region was obtained from $O$. aff. villosula DNA by PCR using the following primers: 28ii 5' ggc tct tcc tat cat tgt gaa gca gaa ttc ac3', 18i $5^{\prime}$ ttt ctc agg ctc cct ctc cgg aat cga acc ct $3^{\prime}$ and $18 \mathrm{k} 5^{\prime}$ ccc gtg ttg agt caa att aag ccg cag gc 3' (Hillis and Dixon, 1991). A diagram with the location of the probes is shown in Figure 1.

PCR reactions were carried out in a Perkin Elmer DNA Thermo Cycler (Pec 9600). In the case of the ITS region and the IGS region, PCR amplifications were performed in $50 \mu \mathrm{l}$ of 1x PCR buffer (Life Technologies, USA), $200 \mu \mathrm{M}$ of each deoxyribonucleotide triphosphate, $300 \mathrm{nM}$ of each primer ITS4 and ITS5 or 300nM of each primer IGS1 and IGS2, and 2.5 units of Taq polymerase (Life Technologies, USA). The IGS region was amplified using the Taq polimerasa "Expand Long Template PCR System" (Roche 
Applied Science, Germany) according to manufacturer's instructions. For the ITS region, the reaction was performed for 40 cycles. Each cycle lasted for $30 \mathrm{sec}$ at $94^{\circ} \mathrm{C}, 1 \mathrm{~min}$ at $50^{\circ} \mathrm{C}$ and $2 \mathrm{~min}$ at $72^{\circ} \mathrm{C}$. In the case of the IGS region the reaction was perfomed for 35 cycles. Each cycle lasted for $1 \mathrm{~min}$ at $94^{\circ} \mathrm{C}, 2 \mathrm{~min}$ at $60^{\circ} \mathrm{C}$ and $5 \mathrm{~min}$ at $72^{\circ} \mathrm{C}$. In both cases, denaturation of the template was performed for $5 \mathrm{~min}$ at $94^{\circ} \mathrm{C}$. A final extension step was carried out for $10 \mathrm{~min}$ at $72^{\circ} \mathrm{C}$.

Extracted DNAs from different species were amplified using primers and PCR procedures described above. PCR amplification showed bands with different lengths between 2 and 4. PCR products were cloned into the pGEM-T easy plasmid (Promega Biotech, EUA) according to manufracturer's instructions. A PCR product of $2,4 \mathrm{kbp}$ from O. peduncularis (AY 356350) was sequenced in the DNA Sequencing Facility at the BioResources Center of Cornell University, Ithaca, NY.

The search of tandem repeat motifs was performed with the Tandem Finder Repeat program (Benson, 1999). Multiple sequence alignment was carried out with CLUSTALX version 1.8 (Thompson et al. 1997).

\section{RESULTS}

Variation in rDNA organization in the genomes of selected species of Oxalis (O. oblongiformis, O. peduncularis, $O$. tabaconasensis, $O$. aff. villosula and $O$. tuberosa) was analyzed by RFLP using different combinations of restriction endonucleases and probes. They were cleaved using the restriction endonucleases EcoRI, BamHI, EcoRIBamHI (double digestion) and EcoRV. Southern blots were probed with: a) the insert present in plasmid pTA71 (comprising the entire wheat rDNA repetition unit); b) the so-called "ITS probe" (a region comprising the internal transcribed spacers ITS1 and ITS2 and the 5.8S rRNA gene); c) a fragment of the 25S rRNA gene and d) the IGS sequence from $O$. aff. villosula.

\section{Restriction endonuclease mapping of Oxalis rDNA repetition unit}

Hybridization experiments with wheat rDNA contained in plasmid pTA71 allowed the proper estimation of the repeat unit size. After digestion with EcoRV a singleband pattern of approximately $11 \mathrm{kbp}$ was obtained in O. tuberosa (Figure 2a). This estimation was supported by the pattern of bands generated after BamHI digestion. Two bands summing up $10.7 \mathrm{kbp}(6.8 \mathrm{kbp}$ and $3.9 \mathrm{kbp})$ were detected (Figure $2 \mathrm{~b}$ ). Since the $6.8 \mathrm{kbp}$ band also hybridized with the $25 \mathrm{~S}$ probe and the $3.9 \mathrm{kbp}$ one to the ITS probe (see below) it was possible to ascribe the sequences present in these bands (25S coding segment and ITS and their respective flanking regions, Figure 6).

The $3.9 \mathrm{kbp}$ band resulting from BamHI digestion (Figure 3) was monomorphic for all the species analyzed, in contrast, digestion with EcoRI evidenced polymorphism: a fragment of $3.5 \mathrm{kbp}$ hybridizing to the ITS probe was characteristic of the genomes of $O$. tuberosa, $O$. tabaconasensis and $O$. oblongiformis while two bands (of $3.9 \mathrm{kbp}$ and $3.5 \mathrm{kbp}$ ) were detected in O. peduncularis and $O$. aff. villosula genomes. After BamHI- EcoRI double digestion, a hybridization band of $2.5 \mathrm{kbp}$ was detected in $O$. oblongiformis and $O$. tuberosa while a $2.9 \mathrm{kbp}$ band was detected in $O$. peduncularis and $O$. aff. villosula and two bands (of $2.9 \mathrm{kbp}$ and $2.5 \mathrm{kbp}$ ) were present in $O$. tabaconasensis.

When BamHI digested genomic DNA was hybridized with the 3 ' region of the $25 \mathrm{~S}$ rDNA probe, different patterns of bands were revealed in the analyzed species perhaps reflecting length variation in the IGS (Figure 4): a band of $6.8 \mathrm{kbp}$ in O. tuberosa, a $7.4 \mathrm{kbp}$ band in O. oblongiformis and a smeared group of bands showing predominant intensity at about $6.9 \mathrm{kpb}$ in $O$. aff. villosula, two bands of $6.9 \mathrm{kbp}$ and $7.4 \mathrm{kbp}$ in O. tabaconasensis and a band of 7.4 $\mathrm{kbp}$ in $O$. peduncularis. While the pattern of hybridization with this probe ( 3 ' end of $25 \mathrm{~S}$ rDNA) after EcoRI digestion was the same as the one obtained after the hybridization with the ITS, the double digestion with EcoRI and BamHI resulted in the occurrence of $2.5 \mathrm{kbp}$ and $1 \mathrm{kbp}$ in $O$. tuberosa, O. tabaconasensis and O. oblongiformis. In $O$. aff. villosula three bands were detected $(3.7 \mathrm{kbp}, 3.2 \mathrm{kbp}$ and $2.7 \mathrm{kbp}$ ) while $O$. peduncularis showed five hybridization bands (of $3.8 \mathrm{kbp}, 3.4 \mathrm{kbp}, 2.8 \mathrm{kbp}, 2.6 \mathrm{kbp}$ and $2.5 \mathrm{kbp}$ and the same bands at $1 \mathrm{kpb}$ ).

An interesting observation of these experiments is that EcoRI digested genomic DNA of $O$. peduncularis and $O$. aff. villosula, probed either with the ITS region or with the $3^{\prime}$ end of the $25 \mathrm{~S}$ resulted in bands of highermolecular weight than expected (Figure 3 and Figure 4). This is possibly due to the lack of an EcoRI site caused by methylation as reported in Solanum (Borisjuk et al. 1994) and in Lycopersicom esculentum (Kiss et al. 1989) or due to a restriction site mutation. In this context, the two fragment pattern of $O$. peduncularis can be explained as a product of the coexistence of these two possible forms. In $O$. peduncularis both forms are more or less equally represented, while in $O$. aff. villosula the hypothetically methylated or mutated band preponderated.

This complexity of patterns that result from a combination of polymorphism, heterogeneity and, in the case of $O$. tuberosa, polyploidy makes it difficult to precisely elucidate the variation of rDNA organization. The interpretation of the described restriction patterns led to the O. tuberosa restriction map proposed in Figure 6.

\section{Restriction endonuclease mapping of the IGS}

After hybridization of BamHI digested DNA with the IGS probe, banding patterns were coherent with the ones detected after hybridization with the $3{ }^{\prime} 25 \mathrm{~S}$ probe. These results suggest the absence of BamHI sites in the IGS 
Table 2. IGS tandem repeat characterization.

\begin{tabular}{|c|c|c|c|c|c|c|c|c|c|c|}
\hline Indices $^{\mathbf{a}}$ & $\begin{array}{c}\text { Period } \\
\text { Size }^{\mathbf{b}}\end{array}$ & $\begin{array}{c}\text { Copy } \\
\text { Number }^{\mathbf{c}}\end{array}$ & $\begin{array}{c}\text { Consensus } \\
\text { Size }^{\mathbf{d}}\end{array}$ & $\begin{array}{c}\text { Percent } \\
\text { Matches }^{\mathbf{e}}\end{array}$ & $\begin{array}{c}\text { Percent } \\
\text { Indels }^{\mathbf{f}}\end{array}$ & A & C & G & T & $\begin{array}{c}\text { Entropy }^{\mathbf{g}} \\
\mathbf{( 0 - 2 )}\end{array}$ \\
\hline $1000--1130$ & 62 & 2.1 & 62 & 85 & 5 & 31 & 28 & 27 & 12 & 1.93 \\
\hline $1301-1725$ & 62 & 6.9 & 61 & 80 & 7 & 27 & 27 & 29 & 15 & 1.96 \\
\hline $1490--1659$ & 31 & 5.5 & 30 & 67 & 17 & 28 & 27 & 29 & 14 & 1.95 \\
\hline
\end{tabular}

${ }^{\mathrm{a}}$ Indices of the repeat relative to the start of the sequence.

${ }^{\mathrm{b}}$ Period size of the repeat.

${ }^{c}$ Number of copies aligned with the consensus pattern.

${ }^{d}$ Size of consensus pattern.

${ }^{\text {e }}$ Percent of matches between adjacent copies overall.

${ }^{f}$ Percent of indels between adjacent copies overall.

${ }^{9}$ Entropy measure based on percent composition.

region (Figure 5) of the different species with the exception of $O$. oblongiformis, where three faint bands could be detected, indicating the specific presence of up to three BamHI sites in some rDNA units in this species. When genomic DNA was digested with EcoRI and hybridized with the same probe, O. tuberosa showed a group of 3 bands of around $4 \mathrm{kbp}(4070 \mathrm{bp}, 3890 \mathrm{bp}$ and $3710 \mathrm{bp}$ ) and another group of 3 bands of around $2 \mathrm{kbp}(2240 \mathrm{bp}, 2060$ bp and $1880 \mathrm{bp}$ ). In agreement with these results, the two groups of bands were conserved after double digestion with BamHI and EcoRI. Compared to EcoRI patterns, the $2 \mathrm{kbp}$ group remained unchanged while the $4 \mathrm{kbp}$ group was reduced to $3 \mathrm{kbp}$ due to the BamHI site (see B1 in Figure 6 map) present in the $18 \mathrm{~S}$ (Figure 5).

Taken together, the two results indicate that at least 3 variants of rDNA units coexist in $O$. tuberosa genome differing in their presence/absence of EcoRI sites or/and number of subrepeats in the IGS.

The patterns observed in the diploid species (O. peduncularis, $O$. tabaconasensis and $O$. aff. villosula) after digestion with EcoRI showed the presence of the same group of bands of around $4 \mathrm{kbp}$ and an additional group of fragments giving rise to a typical ladder ranging from 2700 bp to 200 bp (Figure 5), suggesting the existence of seven subrepeats of approximately $170 \mathrm{bp}$ each, some of which could remain linked after digestion when the Eco RI site was modified. Double digestion of DNA showed the same EcoRI pattern except for the $4 \mathrm{kbp}$ bands which were replaced by $3 \mathrm{kbp}$ bands, as happened in O. tuberosa. This IGS subrepeat organization and the putative polymorphism in the number of subrepeats could explain the smeared pattern of bands observed in these particular species after BamHI digestion. Figure 7 shows an interpretation model for the resulting ladder. Further localization of the subrepeats within the IGS was achieved by mapping the ladder using a more limited probe, just comprising the $3^{\prime}$ end of the $25 \mathrm{~S}$ gene and $200 \mathrm{bp}$ of the $5^{\prime}$ IGS end. Hybridization with this probe revealed a shorter ladder ranging from 2.7 to $1.4 \mathrm{kbp}$ which was compatible with both, the number and the length of the proposed sub repeats (data not shown).Thus, the putative position of the array was at approximately $1 \mathrm{kpb}$ from the 5' IGS end.

An exception to the general IGS organization of diploid species was the case of $O$. oblongiformis, which showed a completely different banding pattern, since BamHI and EcoRI, as well as the double digestion rendered a single high molecular weight band with high intensity and three bands with less intensity after BamHI digestion. These results indicated the lack of EcoRI sites in the IGS region of $O$. oblongiformis and the presence of three BamHI sites in some of the copies, as already described above (Figure $5)$.

\section{IGS nucleotide sequence}

A fragment of 1725 nucleotides of $O$. peduncularis IGS was sequenced (GenBank accession: AY 356350) because it includes the region that revealed the characteristic ladder pattern using probe d (Figure 1) in Southern blot experiments in $O$. peduncularis, in $O$. tabaconasensis and in O. aff. villosula species (Figure 5). Comparison of this sequence with other similar sequences deposited in Genbank showed that although there is very low holomogy with the IGS sequences of other plants, some short conserved motifs could be identified. These motifs (CTTTT, CCCTCCC, TGAAAAT and its variant GAAAAT) probably represent regulatory elements required for transcription initiation and termination processes (Jeandroz et al. 1996; Volkov et al. 1996; Volkov et al. 1999b; Fernández et al. 2000). Interestingly, comparative sequence analysis of the $5^{\prime}$ and $3^{\prime}$ IGS extremes of this and the rest of the Oxalis species studied here revealed a relatively high degree of conservation since sequence 
homology ranged from 90 to $92.5 \%$ (not shown). Thus, as previously reported for other species, the highly polymorphic characteristic of this region was mainly based on the variable numbers of tandem repeats. Three kinds of tandem repeat elements could be defined as characteristic of Oxalis peduncularis: the A repeat type, a $62 \mathrm{bp}$ element present two times between the 1000 and 1130 positions of the cloned fragment; the B repeat type, a 62 bp element repeated seven times between positions 1301 and 1725 and the $\mathrm{C}$ repeat, which was a subrepeat of $31 \mathrm{bp}$ contained within the B repeat type (Table 2 and Figure 8). As happens in other systems, these repeated motifs were not always identical. In this context, the most interesting one was the motif of B type repeats which showed Eco RI restriction endonuclease site polymorphism. The alignment of $\mathrm{B}$ repeats is shown in Figure 8 IV. Presence of an EcoRI site in one of the repeats is marked and its deficiency due to one nucleotide mutation is pointed out in the other repeats.

\section{DISCUSSION}

RFLP analysis of general rDNA organization in Oxalis ( $O$. oblongiformis, O. peduncularis, O. tabaconasensis, O. aff. villosula and $O$. tuberosa) shows that they share the same general organization found in many plants species, particularly the location of BamHI, EcoRI and EcoRV restriction endonuclease sites found here are essentially as those found in other species (see Doyle and Beachy, 1985; Rogers and Bendich, 1987; Zimmer, 1988; Crisci et al. 1990; Lakshmikumaran et al. 1994; Warpeha et al. 1998; Bhagwat et al. 2001; Pillay and Kenny, 2006, for some examples).

Restriction site mapping organization of the transcribed rDNA unit of $O$. tuberosa is very similar to $O$. oblongiformis and both species differ from the others particularly when mapping EcoRI restriction endonuclease sites within the $3^{\prime}$ region of the $25 \mathrm{~S}$ ribosomal gene. The precise analysis was difficult due to heterogeneity in rDNA repetition unit composition due to variation of EcoRI sites in O. peduncularis, $O$. aff. villosula and $O$. tabaconanensis (Figure 2 and Figure 3). This reminds similar observations reported in Solanum (Borisjuk et al. 1994) and in Lycopersicom esculentum (Kiss et al. 1989) where it was proposed the occurrence of methylation. Methylation is a matter of discussion for some authors (Cluster et al., 1996) and other explanations were proposed, i.e. in Solanum Harding (1991) proposed a deletion/insertion of a 100/150 bp near the $3^{\prime}$ end of the $25 \mathrm{~S}$. From the data shown in Oxalis, it is not possible to decide between these two hypotheses, but having in mind that gene conversion is one of the mechanisms proposed for the homogenization process and that it depends on the methylation degree (Lim, 2000), our results would probably agree with the methylation hypothesis. In any case, these results suggest that gene conversion has not homogenised repeat length in Oxalis peduncularis, $O$. aff. villosula and $O$. tabaconanensis.
Despite this general organization similarity to other plant species, specificities are also clear, particularly when mapping EcoRI restriction endonuclease sites within the IGS region. Interspecies homology comparison between spacer regions located between rDNA coding regions show extensive sequence divergence compared to the conserved coding regions. The presence of tandem subrepeats in IGS organization is a common feature in different plant species. However the length, the sequence and the structure vary between species (Appels and Dvorak, 1982; May and Appels, 1987; Rocheford et al. 1990; Jeandroz et al. 1996; Warpeha et al. 1998; Fernández et al. 2000; Gupta et al. 2002, for some examples). RFLP analysis after IGS region hybridization after EcoRI digestion revealed a ladder pattern in the diploid species and poliploid species (except in O. oblongiformis). While in the diploid species the ladder consists in multiples of about $170 \mathrm{bp}$ (160-180 bp), in the octoploid, the bands differ in 200 bp multiples (190$210 \mathrm{bp}$ ), suggesting a different evolution process of the IGS sequences. Although $O$. oblongiformis failed to show the ladder pattern after EcoRI digestion, cross hybridization experiments using the $5^{\prime}$ end of IGS as probe revealed identical Southern banding patterns. Thus, in spite of the fact that $O$. oblongiformis lacks EcoRI sites in the IGS, its sequence ought to be very similar to the rest of the diploid species. In conclusion, the absence of EcoRI sites does not mean the absence of the subrepeats.

As previously reported for other species, the sequence of part of the IGS region in O. peduncularis confirmed that the highly polymorphic characteristic of this region could be mainly based on the variable numbers of tandem repeats. Three kinds of tandem repeat elements ranging from 31 to 62 in length could be defined as characteristic of Oxalis. In agreement with published data from other plant species, the length of IGS sub-repeats, within most individual species, does not seem to differ by more than a few base pairs and their sequences show a high degree of similarity. Among these differences, one of the sub-repeat types showed a variable EcoRI recognition sequence; similarly to the previously described BamHI site found in Sisymbrium irio (Grellet et al. 1989). Although not thoroughly analyzed here, it is likely that rDNA unit heterogeneity and polymorphism is due to variation in the number of subrepeats within an rDNA repeat, as happens at different NOR loci between and within individual species and sometimes at the same NOR locus in different individuals of the same species.

Estimated length sub repeat from the southern blot experiments was $170 \mathrm{bp}$ (160-180 bp), although this length does not strictily matches with tandem sub-repeats of $62 \mathrm{bp}$ found in the sequenced clone, these subrepeats and the EcoRI sites (both complete and deficient) suggest how could the IGS be structured. It is possible that the $170 \mathrm{bp}$ variants could be generated from a $62 \mathrm{bp}$ (or $31 \mathrm{bp}$ ) ancestral motif that could have been submitted to repetition steps leading to a $170 \mathrm{bp}$ block and that subsequent amplification steps have given rise to the present structure, 
a similar situation was observed in the crucifer Sisymbrium irio. IGS region presents some short motifs which are highly conserved in some plants, these sequences were proposed to be involved in signaling RNA transcription and processing. This could be interpreted as an indirect evidence supporting that these sub-repeats may have functions acting as enhancers of transcription (Jeandroz et al. 1996).

Hence, IGS may have evolved in different ways in Oxalis: by varying its sub-repeat lengths and by losing or acquiring the EcoRI sites. A similar situation occurs in Nicotiana tomentosiformis and $N$. sylvestris (two close diploid relatives of the allotetraploid $N$. tabacum), where the subrepeats have very similar in sequence $(90 \%)$, but they differ for the presence of a Cla I site (Volkov et al. 1996).

EcoRI ladder patterns observed in the IGS (present in O. peduncularis, $O$. tabaconasensis and $O$. aff. villosula) revealed the presence of multiple rDNA families and incomplete homogenization. Variation in the intensity of the bands (depending on the species analyzed) was detected, thus indicating different degrees of the homogenization.

Particularly, O. tabaconasensis showed higher relative intensity in some of the IGS bands representing a relatively abundant rDNA family as happen in Nicotiana (Lim et al. 2004). This differential degree of homogenization observed in the IGS of $O$. tabaconanensis is consistent with EcoRI restriction site patterns in the transcribed region (ITS + $25 \mathrm{~S}$ ) which also shows homogenization of the number of bands respect to $O$. peduncularis and $O$. aff. villosula.

The IGS can go through different evolutionary processes in the poliploid species: in some cases, as in the allotetraploids Tragopogon mirus and T. miscellus, IGS could be a usefull tool to identify the different genomes that contribute in the poliploid formation (Kovarik et al. 2005). In other cases the rDNA of one parent is eliminated from the genome as in Nicotiana tabacum (Volkov et al. 1999a) or the case of Nicotiana rustica, an allotetraploid, where the $80 \%$ of its IGS sequences are of an $N$. undulata type, one of the diploids progenitor (Matyasek et al. 2003). The other possibility is the case where parental IGS variants are not represented in the interspecific hybrid or autopoliploid, as in the genera Nicotiana (Kovarik et al. 1996), Oryza (Cordesse et al. 1990) and Medicago (Cluster et al. 1996). The studies by Skalická et al. (2003) in a synthetic tobacco allotetraploid line are interesting as well; he observed that unidirectional gene conversion of rDNA untis may occur and also that newly amplified rDNA units may be identified.

The fact that none of the diploid species share the IGS pattern of the octoploid (O. tuberosa) does not rule out the possibility that some of these species took part in the evolution of $O$. tuberosa genome. Polyploidization of $O$. tuberosa may resemble the case where parental IGS variants are not represented in the interspecific hybrid or autopoliploid (Kovarik et al. 1996; Cordesse et al. 1990; Cluster et al. 1996; Skalická et al. 2003). Other possibility could be that the diploid species included in this study were not involved in the octoploid origin, in this case, the IGS pattern revealed for $O$. tuberosa was unique enough to be a useful tool for prospection in other species that belong to the $O$. tuberosa chromosome alliance.

The comparison of restriction site conservation located in more conserved regions of the cistron in O. tuberosa and $O$. oblongiformis showed remarkably identical restriction patterns for the transcribed rDNA regions while the other diploid species showed some differences, indicating that rDNA organization of these two species is closely related, despite of the IGS data. This observation is in better agreement with the traditional taxonomy since both species are the only ones among those studied here that were classified in the same section by Knuth (in Ortgiesae) and by Lourteig (in Lotoideae).

In spite of the apparent failure of IGS to clarify phylogenetic relationships between the octoploid and the diploid species included in this study, it is interesting to notice that three diploid species (O. peduncularis, $O$. tabaconasensis and $O$. aff. villosula) shared the same IGS pattern, thus suggesting that they could be closely related. However, this conclusion is in conflict with morphologically based taxonomy since these three species were classified by Knuth (1930) in three different sections, while Lourteig separated them into two different sections. Furthermore, the analysis of the IGS variation does not support the proposed sinonimy of $O$. oblongiformis and $O$. tabaconanensis (Lourteig, 2000).

Differences in rDNA organization described in this work showed that the evolution of this part of the genome was very dynamic in this group of species. The molecular mechanisms underlying this evolution seem to combine epigenetic modifications or dynamic mutation of individual tandemly repeated segments with incomplete homogenization. The observed differences could be very helpful to complement other taxonomic criteria.

\section{ACKNOWLEDGMENTS}

We wish to thank to Paula Cohen, Cecilia Tami, Cecilia Vazquez Rovere, and Georgina Barrantes for helpful discussions. We also wish to thank Alicia Lourteig for the encouragement, Luis Fernández for his help, and Cristina Caeli and Betiana Parody for the English assistance.

\section{REFERENCES}

APPELS, R. and DVORÁK, J. The wheat ribosomal DNA spacer region: its structure and variation in populations and among species. Theoretical Applied Genetics, December 1982, vol. 63, no. 4, p. 337-348. 
APPELS, R.; GERLACH, W.L.; DENNIS, E.S.; SWIFT, H. and PEACOCK, W.J. Molecular and chromosomal organization of DNA sequences coding for the ribosomal RNA in cereals. Chromosoma, May 1980, vol. 78, no. 3, p. 293-311.

BALDWIN, B.G.; SANDERSON, M.J.; PORTER, J.M.; WOJCIECHOWSKI, M.F.; CAMPBELL, C.S. and DONOGHUE, M.J. The ITS region of nuclear ribosomal DNA: a valuable source of evidence on angiosperm phylogeny. Annals of the Missouri Botanical Garden, 1995, vol. 82, no. 2, p. 247-277.

BENSON, G. Tandem repeats finder: a program to analyze DNA sequences. Nucleic Acids Research, January 1999, vol. 27 , no. 2 , p. $573-580$.

BHAGWAT, A.S.; KRISHNA, T.G. and MITRA, R.K. Cloning and characterisation of a ribosomal RNA gene repeat unit from groundnut. Plant Cell Reports, March 2001, vol. 20, no. 3, p. 193-197.

BORISJUK, N. and HEMLEBEN, V. Nucleotide sequence of the potato rDNA intergenic spacer. Plant Molecular Biology, January 1993, vol. 21, no. 2, p. 381-384.

BORISJUK, N.; BORISJUK, L.; PETJUCH, G. and HEMLEBEN, V. Comparison of nuclear ribosomal RNA genes among Solanum species and other Solanaceae. Genome, April 1994, vol. 37, no. 2, p. 271-279.

CÁRDENAS, Martín. Manual de plantas económicas de Bolivia. Cochabamba, Bolivia. Imprenta Icthus, 1969. 421 p.

CHOU, C.H.; CHIANG, Y.C and CHIANG, T.Y. Withinand between-individual length heterogeneity of the rDNAIGS in Miscanthus sinensis var. glaber (Poaceae): phylogenetic analyses. Genome, December 1999, vol. 42, no. 6 , p. 1088-1093.

CLEGG, M.T. Molecular diversity in plant populations. In: Brown, A.D.; Clegg, M.T.; Kalher, A.L. and Weir, B.S. eds. Plant Population Genetics, Breeding and Genetics Resources. Sinauer, Sunderland, MA, 1990, p. 98-115.

CLUSTER, P.D.; CALDERINI, O.; PUPILLI, F.; CREA, F.; DAMIANI, F. and ARCIONI, S.l. The fate of ribosomal genes in three interspecific somatic hybrids of Medicago sativa: three different outcomes including the rapid amplification of new spacer-length variants. Theoretical Applied Genetics, October 1996, vol. 93, no. 5-6, p. 801808.

CORDESSE, F.; SECOND, G. and DELSENY, M. Ribosomal gene spacer length variability in cultivated and wild rice species. Theoretical Applied Genetics, January 1990, vol. 79, no. 1, p. 81-88.
CRISCI, J.; ZIMMER, E.; HOCH, P.; JOHNSON, B.; MUDD, C. and PAN, N. Phylogenetic implications of ribosomal DNA restriction site variation in the plant family Onagraceae. Annals of the Missouri Botanical Garden, January 1990, vol. 77, no. 3, p. 523-538.

CRONQUIST, Arthur. An integrated system of classification of flowering plants. New York; Columbia University Press, 1981. 1262 p. ISBN 0-231-038801.

DE AZKUE, Daniel and MARTÍNEZ, Arturo. The chromosome complements of shrubby Oxalis species from South America. Plant Systematics and Evolution, September 1983, vol. 141, no. 3-4, p. 187-197.

DE AZKUE, D. and MARTÍNEZ, A. Variación en el cariotipo, volumen nuclear y contenido de ADN en 7 especies afines de Oxalis. Darwiniana, 1984, vol. 25, no 14, p. 267-277.

DE AZKUE, D. and MARTÍNEZ, A. DNA content and chromosome evolution in the Shrubby Oxalis. Genome, February 1988, vol. 30, no. 1, p. 52-57.

DE AZKUE, Daniel and MARTÍNEZ, Arturo. Chromosome number of the Oxalis tuberosa alliance (Oxalidaceae). Plant Systematics and Evolution, March 1990, vol. 169, no. 1-2, p. 25-29.

DELLAPORTA, S.L. Plant DNA minipreparation: version II. Plant Molecular Biology Reporter, September 1983, vol. 1, no. 4, p. 19-21.

DOYLE, J.J. and BEACHY, R.N. Ribosomal gene variation in soybean (Glycine) and its relatives. Theoretical Applied Genetics, July 1985, vol. 70, no. 4, p. 369-376.

ELDER, J.K. and SOUTHERN, E.M. Measurement of DNA length by gel electrophoresis II: Comparison of methods for relating mobility to fragment length. Analytical Biochemistry, January 1983, vol. 128, no. 1, p. 227-231.

EMSHWILLER, E. and DOYLE, J.J. Origins of domestication and polyploidy in oca (Oxalis tuberosa: Oxalidaceae): nrDNA ITS data. American Journal of Botany, July 1998, vol. 85, no. 7, p. 975-985.

EMSHWILLER, E. and DOYLE, J.J. Chloroplastexpressed glutamine synthetase (ncpGS): potential utility for phylogenetic studies with an example from Oxalis (Oxalidaceae). Molecular Phylogenetics and Evolution, August 1999, vol. 12, no. 3, p. 310-319.

EMSHWILLER, E. and DOYLE, J.J. Origins of domestication and polyploidy in oca (Oxalis tuberosa: Oxalidaceae). 2. Chloroplast-expressed glutamine synthetase data. American Journal of Botany, July 2002, vol. 89, no. 7, p. 1042-1056. 
FERNÁNDEZ, M.; POLANCO, C.; RUIZ, M.L. and PÉREZ DE LA VEGA, M. A comparative study of the structure of the rDNA intergenic spacer of Lens culinaris Medik., and the other legume species. Genome, August 2000, vol. 43, no. 4, p. 597-603.

GERLACH, W.L. and BEDBROOK, J.R. Cloning and characterization of ribosomal RNA genes from wheat and barley. Nucleic Acids Research, December 1979, vol. 7, no. 7, p. 1869-1885.

GRELLET, F.; DELCASSO-TREMOUSAYGUE, D. and DELSENY, M. Isolation and characterization of an unusual repeated sequence from the ribosomal intergenic spacer of the crucifer Sisymbrium irio. Plant Molecular Biology, June 1989, vol. 12, no. 6, p. 695-706.

GUPTA, P.K.; SHARMA, P.K.; BALYAN, H.S.; ROY, J.K.; SHARMA, S.; BEHARAV, A. and NEVO, E. Polymorphism at rDNA loci in barley and its relation with climatic variables. Theoretical Applied Genetics, February 2002, vol. 104, no. 2-3, p. 473-481.

HARDING, K. Restriction enzyme mapping of the ribosomal RNA genes in Solanum tuberosum: Potato rDNA restriction enzyme map. Euphytica, June 1991, vol. 54, no. 3, p. 245-250.

HILLIS, D.M. and DIXON, M.T. Ribosomal DNA: Molecular evolution and phylogenetic inference. The Quarterly Review of Biology, December 1991, vol. 66, no. 4, p. 411-453.

HODGE, W.H. Three native tuber foods of the high Andes. Economic Botany, 1951, vol. 5, no. 2, p. 185-201.

HSIEH, H.; HOU, R.J.; CHEN, K.F.; TSAI, L.C.; LIU, S.W.; LIU, K.L.; LINACRE, A. and LEE, J.C.I. Establishing the rDNA IGS Structure of Cannabis sativa. Journal of Forensic Sciences, May 2004, vol. 49, no. 3, p. 477-480.

HSIEH, HSING- MEI; LIU, CHIA-LING; TSAI, LICHING; HOU, RUR- JYUN; LIU, KUO-LAN; LINACRE, ADRIAN and LEE, James Chun-I. Characterization of the polymorphic repeat sequence within the rDNA IGS of Cannabis sativa. Forensic Science International, August 2005, vol. 152, no. 1, p. 23-28.

JEANDROZ, S.; PUGIN, A. and BERVILLÉ, A. Cloning and analysis of a $6.8-\mathrm{kb}$ rDNA intergenic spacer region of the European ash (Fraxinus excelsior L.). Theoretical Applied Genetics, June 1996, vol. 92, no. 8, p. 1003-1008.

KING, S.R. Four endemic Andean tuber crops: promising food resources for agricultural diversification. Mountain Research and Development, February 1987, vol. 7, no. 1, p. 43-52.
KISS, T.; KISS, M. and SOLYMOSY, F. Nucleotide sequence of a 25S rRNA gene from tomato. Nucleic Acids Research, January 1989, vol. 17, no. 2, p. 796.

KOVARIK, A.; FAJKUS, J.; KOUKALOVA, B. and BEZDEK, M. Species-specific evolution of telomeric and rDNA repeats in the tobacco composite genome. Theoretical Applied Genetics, June 1996, vol. 92, no. 8, p. 1108-1111.

KOVARIK, A.; PIRES, J.C.; LEITCH, A.R.; LIM, K.Y.; SHERWOOD, A.M.; MATYASEK, R.; ROCCA, J.; SOLTIS, D.E. and SOLTIS, P.S. Rapid concerted evolution of nuclear ribosomal DNA in two Tragopogon allopolyploids of recent and recurrent origin. Genetics, February 2005, vol. 169, no. 2, p. 931-944.

KNUTH, R. Oxalidaceae. In: ENGLER, A. ed. Das Pflanzenreich. Leipzig, 1930, vol. 4. p. 130-131.

KNUTH, R. Oxalidaceae 2. Repertorium Specierum Novarum Regni Vegetabilis, 1935, vol. 38, p. 194-199.

KNUTH, R. Oxalidaceae 3. Repertorium Specierum Novarum Regni Vegetabilis, 1936, vol. 40, p. 289-293.

LAKSHMIKUMARAN, M.; SINGH, A. and NEGI, M. Structural analysis of two variants of the rDNA intergenic spacer from Eruca sativa. Plant Molecular Biology, March 1994, vol. 24, no. 6, p. 915-927.

LEÓN, J. Plantas alimenticias andinas. Boletín Técnico del Instituto Interamericano de Ciencias Agrícolas. Lima, Perú, 1964, no. 6, p. 15-34.

LIM, K.Y.; KOVARIK, A.; MATÝASEK, R.; BEZDEK, M.; LICHTENSTEIN, C.P. and LEITCH, A.R. Gene conversion of ribosomal DNA in Nicotiana tabacum is associated with undermethylated, decondensed and probably active gene units. Chromosoma, June 2000, vol. 109, no. 3, p. 161-172.

LIM, K.Y.; SKALICKA, K.; KOUKALOVA, B.; VOLKOV, R.A.; MATYASEK, R.; HEMLEBEN, V.; LEITCH, A.R. and KOVARIK, A. Dynamic changes in the distribution of a satellite homologous to intergenic 26-18S rDNA spacer in the evolution of Nicotiana. Genetics, April 2004, vol. 166, no. 4, p. 1935-1946.

LOURTEIG, A. Oxalidaceae. In: REITZ, R., ed. Fl. Il. Catarinense 1. Sta. Catarina Brasil, 1983, p. 1-176.

LOURTEIG, A. Oxalis L. Subgénero Monoxalis (Small) Lourt. Oxalis y Trifidus Lourt. Bradea, 2000, vol. 7, no. 2, p. 201-629.

MAGGINI, F.; TUCCI, G.; DEMARTIS, A.; GELATI, M.T. and AVANZI, S. Ribosomal RNA genes of Phaseolus 
coccineus. I. Plant Molecular Biology, April 1992, vol. 18, no. 8 , p. 1073-1082.

MARKS, G.E. Chromosome numbers in the genus Oxalis. New Phytology, January 1956, vol. 55, no. 1, p. 120-129.

MATYASEK, R.; LIM, K.Y.; KOVARIK, A. and LEITCH, A.R. Ribosomal DNA evolution and gene conversion in Nicotiana rustica. Heredity, September 2003, vol. 91, no. 3, p. 268-275.

MAY, C.E. and APPELS, R. Variability and genetics of spacer DNA sequences between the ribosomal-RNA genes of hexaploid wheat (Triticum aestivum). Theoretical Applied Genetics, September 1987, vol. 74, no. 5, p. 617624.

NARANJO, C.; MOLA, L.M.; POGIO, L. and MULGURA DE ROMERO, M. Estudios citotaxonómicos y evolutivos en especies herbáceas sudamericanas de Oxalis (Oxalidaceae). I Boletín Sociedad Argentina de Botánica, 1982, vol. 20, no. 3-4, p. 183-200.

PILLAY, M. Genomic organization of ribosomal RNA genes in Bromus (Poaceae). Genome, February 1996, vol. 39, no. 1, p. 198-205.

PILLAY, M. and KENNY, S.T. Structural organization of the nuclear ribosomal RNA genes in Cannabis and Humulus (Cannabaceae). Plant Systematics and Evolution, April 2006, vol. 258, no. 1-2, p. 97-105.

POLANCO, C. and PÉREZ DE LA VEGA, M. Intergenic ribosomal spacer variability in hexaploid oat cultivars and landraces. Heredity, February 1997, vol. 78, no. 2, p. 115123.

ROCHEFORD, T.R.; OSTERMAN, J.C. and GARDNER, C.O. Variation in the ribosomal DNA intergenic spacer of a maize population mass-selected for high grain yield. Theoretical Applied Genetics, June 1990, vol.79, no. 6, p. 793-800.

ROGERS, S.O. and BENDICH, A.J. Ribosomal RNA genes in plants: variability in copy number and in the intergenic spacer. Plant Molecular Biology, September 1987, vol. 9 , no. 5, p. 509-520.

SKALICKÁ, $\quad$ K.; $\quad$ LIM, $\quad$ Y.; $\quad$ MATYÁŜEK, $\quad$ R.; KOUKALOVÁ, B.; LEITCH, A. and KOVAŘÍK, A. Rapid evolution of parental rDNA in a synthetic tobacco allotetraploid line. American Journal of Botany, July 2003, vol. 90, no. 7, p. 988-996.

SAGHAI-MAROOF, M.A.; SOLIMAN, K.; JORGENSEN, R. and ALLARD, R. Ribosomal DNA spacer-length polymorphisms in barley: Mendelian inheritance, chromosomal location, and population dynamics. Proceedings of the National Academy of Sciences of the
United States of America, December 1984, vol. 81, no. 24, p. $8014-8018$.

SANO, Y. and SANO, R. Variation of the intergenic spacer region of the ribosomal DNA in cultivated and wild rice species. Genome, April 1990, vol. 33, no. 2, p. 209-218.

STUPAR, R.M.; SONG, J.; TEK, A.L.; CHENG, Z.; DONG, F. and JIANG, J. Highly condensed potato pericentromeric heterochromatin con- tains rDNA-related tandem repeats. Genetics, November 2002, vol. 162, no. 3, p. $1435-1444$.

TAIRA, T.; KATO, A. and TANIFUKI, S. Difference between two major size classes of carrot rDNA repeating units is due to reiteration of sequences of about $460 \mathrm{bp}$ in the large spacer. Molecular General Genetics, July 1988, vol. 213, no. 1, p. 170-174.

THOMPSON, J.D.; GIBSON, T.J.; PLEWNIAK, F.; JEANMOUGIN, F. and HIGGINS, D.G. The CLUSTAL_X windows interface: flexible strategies for multiple sequence alignment aided by quality analysis tools. Nucleic Acids Research, December 1997, vol. 25, no. 24, p. 4876-4882.

TOSTO, D.S. and HOPP, H.E. Sequence analysis of the 5.8S ribosomal DNA and internal transcribed spacers (ITS1 and ITS2) from five species of the Oxalis tuberosa alliance. DNA Sequence, 1996, vol. 6, no. 6, p. 361-364.

TOSTO, D.S. and HOPP, H.E. Suitability of AFLP markers for the study of genomic relationships within the Oxalis tuberosa alliance. Plant Systematics and Evolution, September 2000, vol. 223, no. 3-4, p. 201-209.

VIETMEYER, N.D. Lesser known plants of potencial use in agriculture and forestry. Science, June 1986, vol. 232, no. 4756 , p. $1379-1384$.

VOLKOV, R.A.; KOSTISHIN, S.; EHRENDORFER, F. and SCHWEIZER, D. Molecular organization and evolution of the external transcribed rDNA spacer region in two diploid relatives of Nicotiana tabacum (Solanaceae). Plant Systematics and Evolution, March 1996, vol. 201, no. 1-4, p. 117-129.

VOLKOV, R.A.; BORISJUK, N.V.; PANCHUK, I.; SCHWEIZER, D. and HEMLEBEN, V. Elimination and Rearragement of Parental rDNA in the Allotetraploid Nicotiana tabacum. Molecular Biology and Evolution, March 1999a, vol. 16, no. 3, p. 311-320.

VOLKOV, R.A.; BACHMAIR, A.; PANCHUK, I.I.; KOSTYSHYN, S.S. and SCHWEIZER, D. 25S-18S rDNA intergenic spacer of Nicotiana sylvestris (Solanaceae): primary and secondary structure analysis. Plant Systematics and Evolution, March 1999b, vol. 218, no. 1-2, p. 89-97. 
WARPEHA, K.M.F.; GUILLILAND, T.J. and CAPESIUS, I. An evaluation of rDNA variation in Lolium species (ryegrass). Genome, April 1998, vol. 41, no. 2, p. 307-311.

ZIMMER, E.A.; JUPE, E.R. and WALBOT, V. Ribosomal gene structure, variation and inheritance in maize and its ancestors. Genetics, December 1988, vol. 120, no. 4, p. 1125-1136. 
Tosto, D. and Hopp, E.

\section{APPENDIX \\ FIGURES}

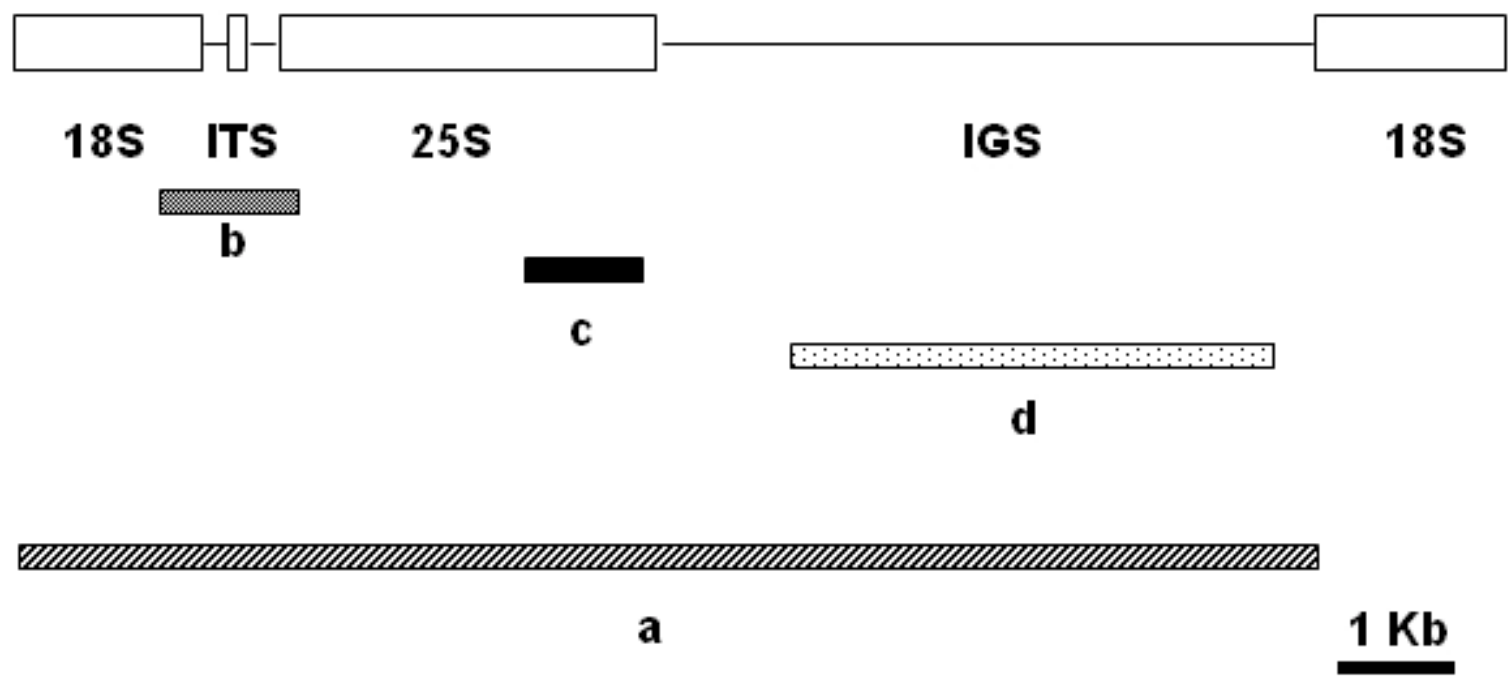

Figure 1. Schematic diagram of plant ribosomal DNA organization and the probes used in this study. Abbreviations on the figure denote the following: 18S: 18S rDNA; ITS: internal transcribed spacer; 25S: 25S rRNA coding region; IGS: intergenic spacer. The position of the probes used for sequential probing is shown below the repeat unit. (a) The $8.95 \mathrm{kbp}$ Eco RI fragment of wheat rDNA cloned in pTA71 (Gerlach and Bedbrook, 1979) as heterologous probe, (b) The internal transcribed spacers ITS1, 5.8S and ITS2 rDNA (ITS), (c) An EcoRI- BamHI fragment (1000 bp) corresponding to the 3' end of the 25S fragment of wheat rDNA (May and Appels, 1987), (d) The intergenic spacerlGS region. 
a

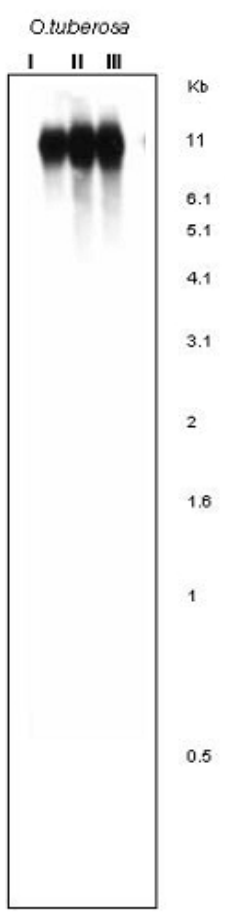

b
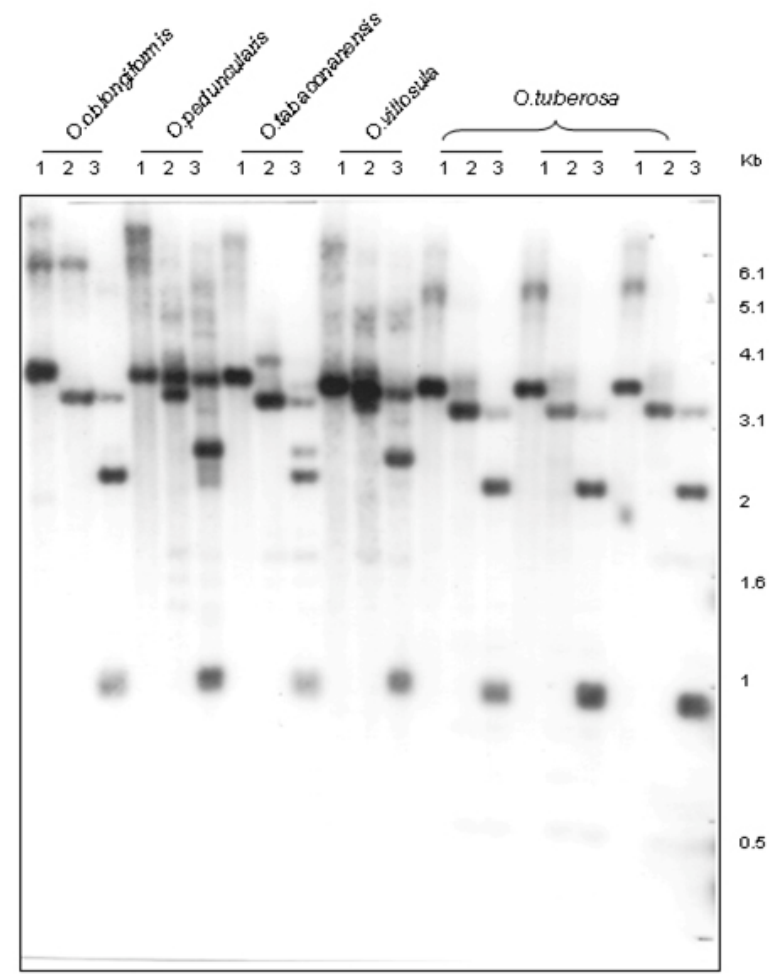

Figure 2. Hybridizaton patterns of Oxalis nuclear DNA RFLPs hybridized with the pTA71 probe (wheat heterologous probe of the entire repeat).

(a) EcoRV digested DNA from O. tuberosa, lanes: I, II, III, three different accessions of O. tuberosa (No 1074, 1148 and 1051, respectively).

(b)Total digested DNA from Oxalis species, lanes 1: digested by BamHI, lanes 2: digested by EcoRI and lanes 3: the double digestion BamHI- EcoRI. Numbers in top denote the different plants, 1: O. oblongiformis, 2: O. peduncularis, 3: O. tabaconasensis, 4: O. aff. villosula, 5, 6, 7: O. tuberosa (acc. No 1074, 1051 and 1018 respectively). 
Tosto, D. and Hopp, E.

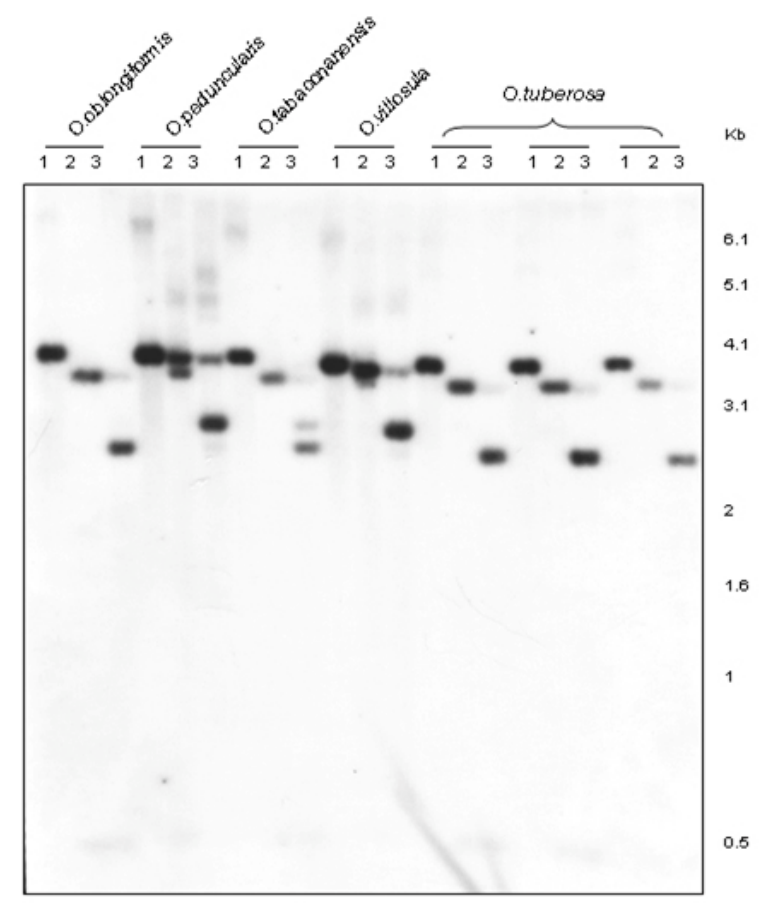

Figure 3. Hybridization patterns of Oxalis nuclear DNA RFLPs hybridized with the ITS probe. Lanes 1: BamHI digestion, lanes 2: EcoRI digestion, lanes 3: double digestion BamHI- EcoRI. Numbers in top in denote the different plants, 1: 0 . oblongiformis, 2: 0. peduncularis, 3: O. tabaconasensis, 4: O. aff. villosula, 5, 6, 7: O. tuberosa (acc. No 1074, 1051 and 1018 respectively).

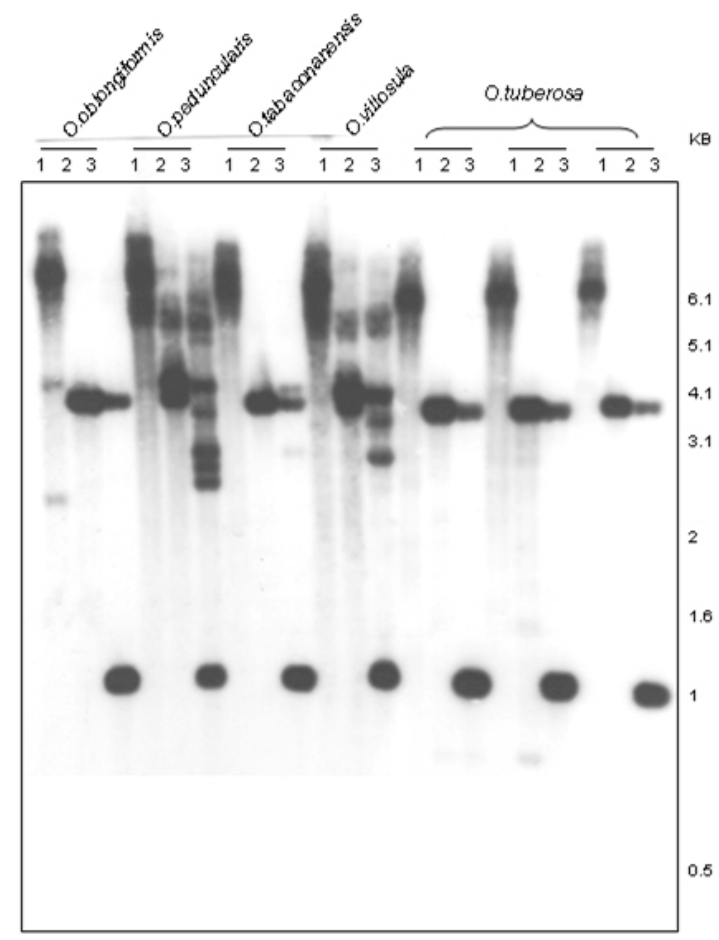

Figure 4. Hybridization patterns of Oxalis nuclear DNA RFLPs hybridized with the $25 \mathrm{~S}$ probe. Lanes 1: BamHI digestion, lanes 2: EcoRI digestion, lanes 3: double digestion BamHI- EcoRI. Numbers in top in denote the different plants, 1: O. oblongiformis, 2: O. peduncularis, 3: O. tabaconasensis, 4: O. aff. villosula, 5, 6, 7: O. tuberosa (acc. No 1074, 1051 and 1018 respectively). 


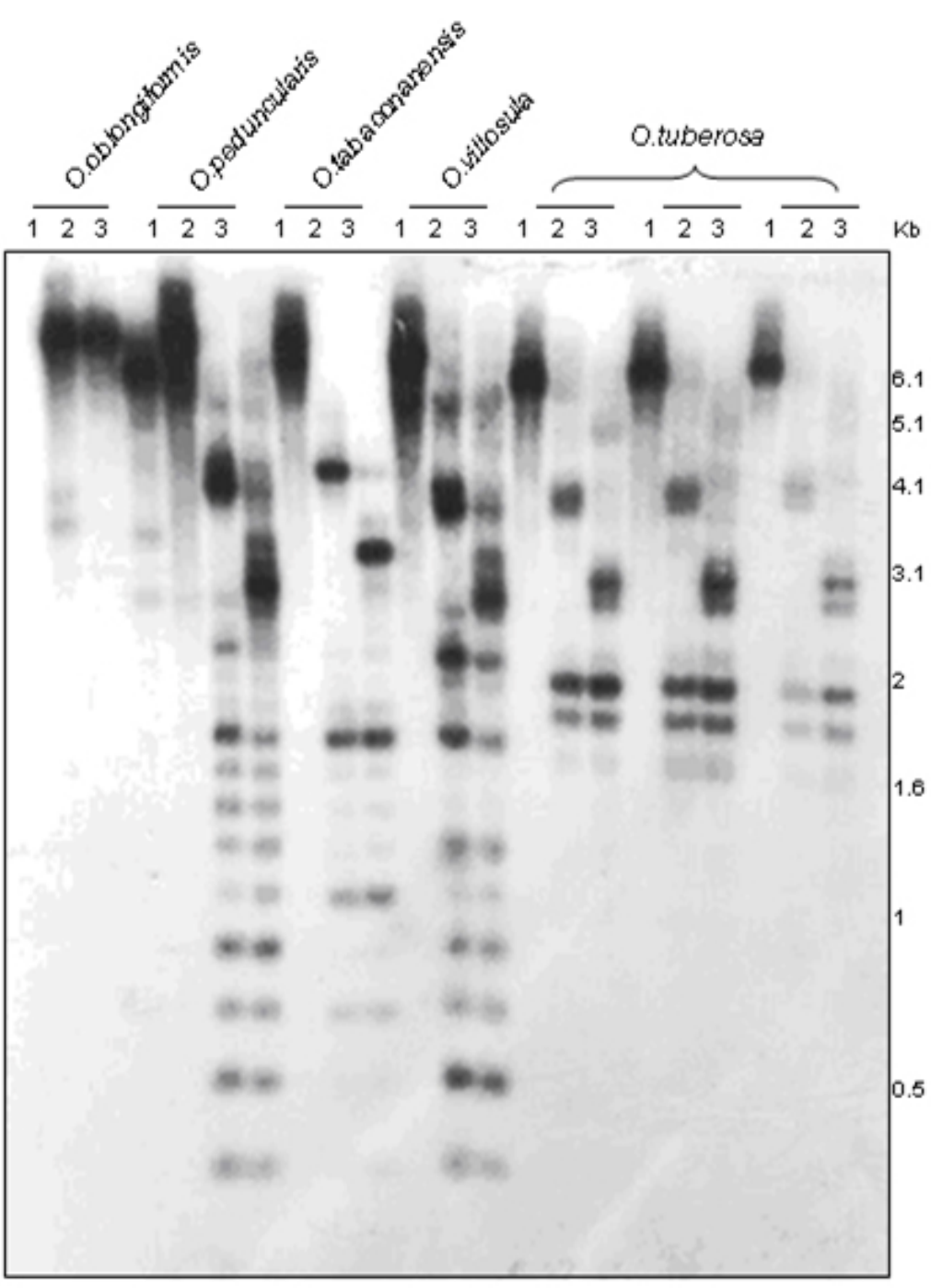

Figure 5. Hybridization patterns of Oxalis nuclear DNA RFLPs hybridized with the IGS probe. Lanes 1: BamHI digestion, lanes 2: EcoRI digestion, lanes 3: double digestion BamHI- EcoRI. Numbers in top in denote the different plants, 1: O. oblongiformis, 2: O. peduncularis, 3: O. tabaconasensis, 4: O. aff. villosula, 5, 6, 7: O. tuberosa (acc. No 1074, 1051 and 1018 respectively).

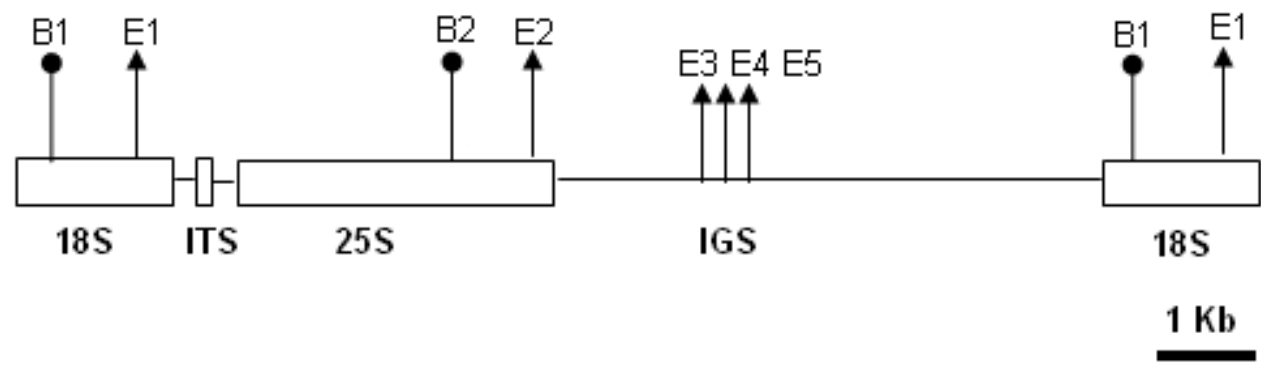

Figure 6. Deduced restriction sites location in nuclear 0 . tuberosa rDNA unit. Diagram is based on the results showed in Figure $2 a$ and in lines corresponding to $O$. tuberosa on Figure $2 b$, Figure 3, Figure 4 and Figure 5 . Abbreviations on the figure denote the following: 18S: 18S rDNA; ITS: internal transcribed spacer; 25S: 25S rRNA coding region; IGS: intergenic spacer. EcoRI (• ), BamHI ( $)$ sites. 
Tosto, D. and Hopp, E.

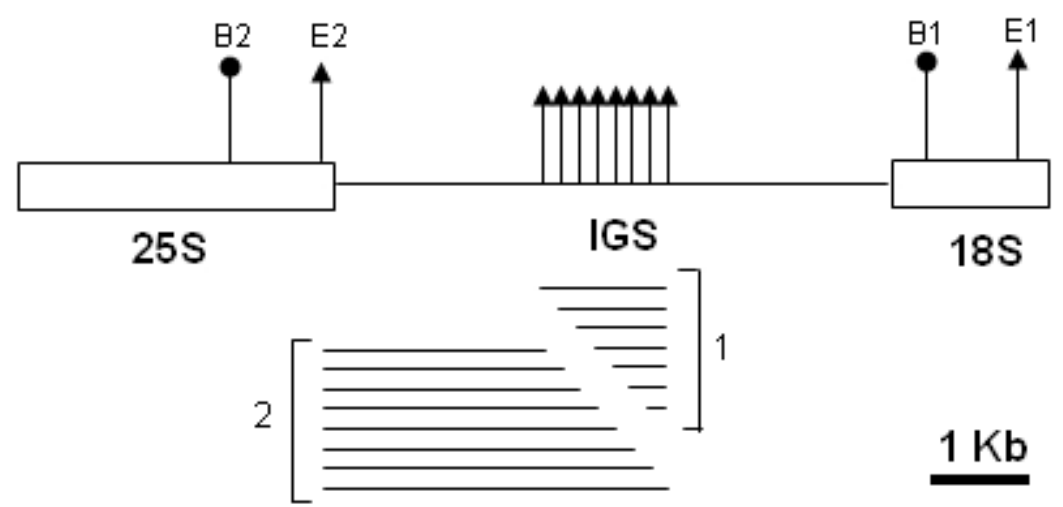

Figure 7. Schematic interpretation of EcoRI restriction patterns of most of diploid species with the IGS probe. Intergenic spacer is shown with its flanking $25 \mathrm{~S}$ and 18S rRNA domains and the putative EcoRI sites are marked ( $\boldsymbol{\bullet}$ ). Bellow, (1) and (2) represent the different EcoRI fragments that could be present. This pattern was observed in the following diploid species: $O$. peduncularis, $O$. tabaconasensis and $O$. aff. Villosula. 
1000 GAGGAAAATAATCC CAAGACCCTA GTTGGCCGAGAGAATTGCACCCCTA-GAGCCGACTGGCC AO GAGGA AAATAATCC CAAGA CCCTA ATTGGCCAAGAGAATTGCAC CCC-AGGAGCCGACTGGCC

$$
\text { * * }
$$

1062 GAGGAMAATGÄ-C CCCATACCCTAATTGGCCAAGAGÄ TTGCA CCCCAGGGGCCGGCTGGCC A0 GAGGAAAAT-AATC CCAAGACCCTAATTGGCCAA GAGAATTGCACCCCAGGAGCCGACTGGCC

1124 GÄGGÄAB

A0 GAGGAAB

II

B Repeats

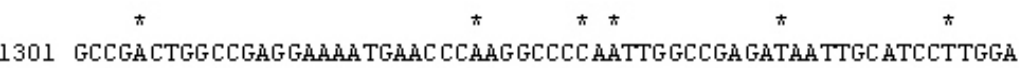

BO GCCGGCTGGCCGÄGGÄAдATGÄAC CCCAGGCCCTAGTTGGCCGÄGÄGÄATTGCA-CCCTGGÄ

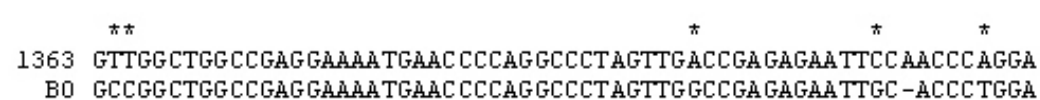

* * * *

1425 GCTGGCCGGCCGAGGÄAAAT---CCCTÄGG-CCTCAGTTGGCCAAGAGAATTGCA-CCTGTAGA

BO GCCGGCTGGCCGAGGABAA TGAAC CCCAGGCCCT-AGTTGGCCGAGAGAATTGCACCCTG--GA

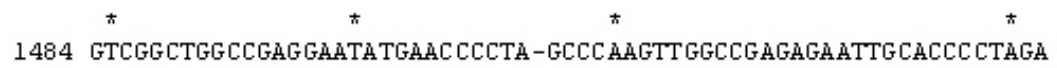

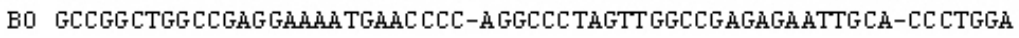

*

1546 GCCGGCTGGCCGAGGAMAA TGAAC CCCAGGCCCTAGTTGGCTGA GAGAM TTGCACCCCTGGA

BO GCCGGCTGGCCGAGGAAAA TGAAC CCCAGGCCCTAGTTGGCCGA GAGAA TTGCA-CCCTGGA

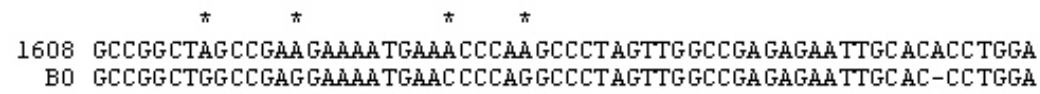

$1670 \stackrel{*}{*} *{ }^{*}$ GCTGGCTAGCCGAGGAAAMTGAAC CCCAAGG-CC GATGTTGGTC GAGAGAATC GCAC

BO GCCGGCTGGCCGAGGAAAATGAACCCC-AGGCCCTA-GTTGGCC GAGAGAATT GCAC

III C Repeats

1490 TGGCCGÄG-GÄATÄTGÄCCC CTÄGC CCÄAGT

CO TGGCCGA GAGAATTGAACCCCT--AGCCCAGT

$$
\text { * } \quad \text { * * }
$$

1521 TGGCCGÄGAGAATTGCACCCCTAGAGCCGGC

CO TGGCCGA GAGAATTGÄACCCCTAG-CCCAGT

\section{*}

1552 TGGCCGAG-GAMAATGAAACCCC-AGGCCCTAGT

CO TGGCCGÄGAG-HATTGAACCC CTA-GCCC-ÄGT

\author{
1583 TGGCTGAGAGAATTGCACC CCTGGAG-CCGGC \\ CO TGGCC GAGAGAATTGAACCCCT--AGCCCAGT

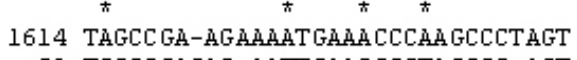 \\ CO TGGCC GAGAG-AATT GAACCCCTAGCCC-AGT \\ 1645 TGGCCGAGAGAATTG \\ CO TGGCC GÄGAGAATTG
}

$\Gamma$

1546 GCCGGCTGGCCGHGGMAMTGAMCCCCAGGCCCTA-GTTGGCTGMGAGAMTTGCACCCCTGGA 1608 GCCGGCTAGCCGM

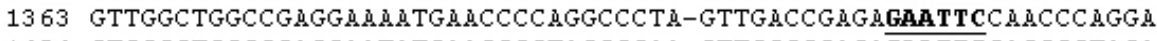

1484 GTCGGCTGGCCGAGGAMTATGAMCCCCTAGCCCAA-GTTGGCCGAGAGAATTGCACCCCTAGA

1670 GCTGGCTAGCCGAGGHAMATGAMCCCCAMGGCCGATGTTGGTCGAGAGAATCGCACC------

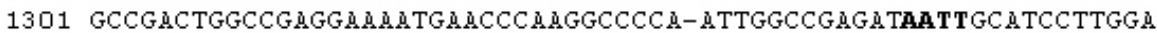

1425 GCTGGCCGGCCGAGGMAMAT--CCCTAGGCCTCA-GTTGGCCAMGAGAATTGCACCTGTAGA

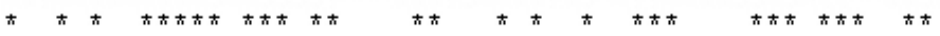

Figure 8. Repeat motives of nucleotide sequence of the rDNA intergenic spacer (IGS) fragment of Oxalis peduncularis (AY 356350). I Alignment of consensus sequence of the type A repeats (A0) with the sequences of each $A$ repeats in $O$. peduncularis performed with the Tandem Finder Program. II Idem for B repeats. III Idem for C repeats. Symbol - indicates an insertion or deletion. Symbol * indicates a mismatch. IV Sequence alignment of B repeats (Clustal X). Perfect (underlined) and mutated EcoRI restriction site recognition sequences are emphasized in bold. Symbol - indicates an insertion or deletion. Symbol * indicates a match. 